\title{
The Problem of Delay in Tort Recovery and the British Interim Payment Scheme
}

Prior to recovery through settlement or judgment, personal injury claimants ${ }^{1}$ must generally use their own resources to meet economic losses $^{2}$ resulting from tortious conduct. ${ }^{3}$ Because of the often lengthy period between injury and recovery, ${ }^{4}$ low and moderate income claimants, who do not have the resources for continued cash outlays and extended self-support, frequently accept the lure of an early settlement. ${ }^{5}$

1 The observations in this comment concerning personal injury claims are derived largely from data reported on automobile accidents, since this source of injuries is responsible for "the chief business of the contemporary tort system," C. GREGORX \& H. KALVEN, CASES AND MATERIALS ON TORTS 782 (1969), and has generated significant studies of the inequities of delayed tort recovery. Studies involving all types of personal injury claims substantially corroborate the findings in the automobile context. Compare, e.g., H. ZEISEL, H. Kaxven \& B. Buchiolz, Delay IN THE COURT (1959); Rosenberg, Court Congestion: Status, Causes, and Proposed Remedies, in H. Jones, The CouRTs, THE PuBlic ANd the LAW 29 (1965); Rosenberg \& Sovern, Delay and the Dynamics of Personal Injury Litigation, 59 Colum. L. Rev. 1115 (1959) with Comer. to Study Compensation for Automobile AcctdeNTS, Report to the Columbia University CouncIl For Research IN the Soctal ScIENces (1932); A. Conard, J. Morgan, R. Pratr, C. Voltz \& R. Bombaugh, Automoblle Accident Costs AND Payments (1964) [hereinafter cited as A. Conard et al.]; and Morris \& Paul, The Financial Impact of Automobile Accidents, 110 U. PA. L. REv. 913 (1962).

2 Economic losses are "those losses which are ordinarily perceived by people as dollar losses-however uncertain in amount," as distinguished from those losses "which are not so measured except in the unobservable process of jury verdicts and judicial findings." A. CONARD et al., supra note 1, at 137-40. Because the latter type of loss, exemplified by an item such as pain and suffering, cannot be estimated objectively, it is invariably excluded from studies on injury loss. See, e.g., id.; 1 U.S. Dep't of Transportation, Automobile Personal Injury Claims (1970) [hereinafter cited as Personal Injury Clatms]; I U.S. Dep't of Transportation, Economic Consequences of Automobile AcGident INJURIES, REPORT OF THE WESTAT CORPORATION (1970) [hereinafter cited as Economic ConsEQUENCES]. The economic loss criterion that is typically used includes three basic categories: (1) expenses incurred (e.g., hospital and medical); (2) lost wages; and (3) estimated future expenses and lost wages. See, e.g., id. at 18, 19.

3 A. Conard et al., supra note 1, at 221; Corstvet, The Uncompensated Accident and Its Consequences, 3 LAW \& Contemp. Prob. 466, 468 (1936).

4 Comm. to Study Compensation for Automobile Accidents, supra note 1, at 92-94; A. ConARD et al., supra note 1, at 221-23, 242-49; ECONOMIC Consequences, supra note 2, at 51-52; R. Keeton \& J. O'Connell, Basic Protection for the Traffic Victim 1-2 (1965); Personal InJURY ClaIMs, supra note 2, at 83-87; James \& Law, Compensation for Auto Accident Victims: A Story of Too Little and Too Late, 26 Coмm. B.J. 70, 76-78 (1952); Marshall \& Berg, In Support of No-Fault Liability: A Reply to the Critique of the New York State Bar Association, 27 Recond of N.Y.C.B.A. 29, 33-34 (1972); Morris \& Paul, supra note 1, at 923-24; Rosenberg \& Sovern, supra note 1, at 1121-24.

5 A. Conard et al., supra note 1, at 221; R. KeEton \& J. O'ConneL, supra note 4, at 2; 
Invariably, the amount accepted is significantly less than that which further negotiations or a suit could have been expected to produce. ${ }^{\circ}$ Although other factors contribute to the chronically weak bargaining position of marginally financed claimants, ${ }^{7}$ the need to meet losses without prolonged delay is particularly important, and its elimination might provide many claimants with a stronger bargaining position and a fairer recovery.

In recent years, two novel forms of assistance have been introduced to meet this problem. The first, advance payment programs, has been adopted by several liability insurers, ${ }^{8}$ and the other, no-fault automobile insurance, has been enacted by a few states. ${ }^{9}$ These responses by the private and public sectors indicate recognition of the inadequacies of the aids traditionally used by financially pressed claimants-loans from friends and relatives, ${ }^{10}$ personal savings, ${ }^{11}$ advances from attorneys, ${ }^{12}$ and compensation from such sources as hospital and medical insurance, sick leave, and workmen's compensation..$^{13}$ It is unlikely, however, that advance payments and no-fault programs will have the desired impact on the problem since they too suffer from severe limitations in the number of claimants that can be helped and the amount of support that can be provided.

An alternative and potentially more successful solution to the problem is suggested by the recent enactment in England of an interim payment plan, ${ }^{14}$ which allows a court to make a pretrial award of

Franklin, Chanin, \& Mark, Accidents, Money and the Law: A Study of the Economics of Personal Injury Litigation, 61 CoLum. L. REv. 1, 30 (1961); James \& Law, supra note 4, at 78; Marshall \& Berg, supra note 4, at 32.

6 Id.

7 Low income families, for example, are less likely to retain counsel than are middle and upper income families. Economic Consequences, supra note 2, at 54. Given the effect of attorney representation on recovery, this fact is certain to place low income families at a distinct disadvantage. See note 37 infra.

8 See, e.g., Defense Research InstTIUte, AdVance Payments-Credit for Payments in advance of Settlement or Trial (1969); U.S. Dep't of Transportation, Motor Vehicle Crash Losses and ThejR Compensation in the United States: A Report to the Congress AND THE PRESDENT 60 (1971); J. O'CoNNELL, The INJURY INDUSTRY 22 (1971); Graham, $A d$ vance Payments in Personal Injury Claims, 3 Forum 208 (1968); Schroeder, Carpenter \& DesChamps, Advance Payments as a New Approach in the Settlement of Liability Claims, 34 INS. COUNSEL J. 550 (1967).

9 See note 79 infra.

10 See, e.g., Economic Consequences, supra note 2, at 57; Morris \& Paul, supra note 1, at 922.

11 Id.

12 F. Mackinnon, Contingent Fefs for legal Services $68-70$ (1964); Comment, Loans to Clients for Living Expenses, 55 CALIF. L. REv. 1419 (1967).

13 See, e.g., EConomic Consequences, supra note 2, at 36-46; A. Conard et al., supra note 1 , at $1-74$.

14 The Administration of Justice Act 1969, c. 58, IV, sec. 20. 
damages upon the application of a plaintiff in a personal injury action..$^{15}$ To qualify for interim payment relief, the plaintiff must demonstrate a need for funds while awaiting a fair settlement offer or trial. ${ }^{16}$ In the two years since its inception, interim payment assistance has enabled substantial numbers of injured parties to avoid inequitable settlements. ${ }^{17}$

This comment discusses the feasibility of using the English interim payment procedure as an alternative method of presettlement assistance in the United States. Following an evaluation of the sources of claimant aid presently available, it analyzes the comparative advantages of an interim payment program and examines the possible difficulties of its adoption.

\section{Examination of the Problem: Tort Recovery}

An injured party may presently obtain compensation from numerous sources, including not only tort recovery but also hospital and medical insurance, workmen's compensation, sick leave, Social Security benefits, and public assistance programs. ${ }^{18}$ Since mere demonstration of loss is often sufficient to obtain aid, ${ }^{19}$ most injured parties recover at least some reparation. ${ }^{20}$ Of those compensated from some source, however, almost half recover from the tort system. ${ }^{21}$ For those who recover in tort through settlement or damage award, tort compensation is typically the largest source of reparation. A recent Department of Transportation study indicates that 60 percent of the total compensation received by persons injured in automobile accidents was recovered through the tort

15 See Stat. InSTR. 1970 No. 944, at 2932.

16 Id. See also I. Jacob, P. Adams, J. Neave, \& K. McGurfie, The Supreme Court PracTICE If 29/9-17/1 (Supp. 1970) [hereinafter cited as Supreme CouRT Practice (Supp. 1970)].

17 Letter from I. Jacob, Master in the Queen's Bench Division, Supreme Court of Judicature, to The University of Chicago Law Review, Feb. 11, 1972 (on file at The University of Chicago Law Review).

18 See A. Conard et al., supra note 1, at 23-74, 137-58; U.S. Dep'T of Transportatron, Motor Vehicle Crash Losses and TheIR Compensation in the UnIred States, supra note 8, at 8-14; ECONOMIC ConsEQUENCES, supra note 2, at 36-46; Conard, The Economic Treatment of Automobile Injuries, 63 MrCH. L. REv. 279, 286-89 (1964); Morris \& Paul, supra note 1, at 919-20.

19 Economic Consequences, supra note 2, at 36.

20 A Department of Transportation study indicates that more than 90 percent of those seriously injured in automobile accidents recovered some form of compensation for economic loss. Id. at 37. In the study of automobile accidents in Michigan, about 75 percent of those who suffered economic loss received some type of reparation. A. CONARD et al., supra note 1 , at $145-46$.

21 Of those parties injured in an automobile accident, 45.9 percent have been reported as receiving tort reparations. Economrc ConsEQUENCES, supra note 2, at 37. 
system.22 At almost all levels of accident losses, tort recovery was responsible for meeting more than twice as much economic loss as any other single source. ${ }^{23}$ These findings, which corroborate those of earlier studies, ${ }^{24}$ demonstrate the central importance of tort recovery to personal injury claimants.

The primary disadvantage of the tort system is the delay between injury and recovery. Studies of personal injury claims arising from automobile accidents indicate, for example, that the average elapsed time between injury and tort settlement is sixteen months; ${ }^{25}$ where economic losses exceed $\$ 2,500$, the average is nineteen months. ${ }^{26}$

Among the factors contributing to delayed tort settlements, perhaps the most important is defendants' lack of incentive to settle early. Aside from an understandable reluctance to part with their funds, defendants who postpone offers of an equitable settlement until immediately prior to trial are supported by a legal system that does not impose penalties for "bad faith" settlement negotiations. Although less than 2 percent of personal injury claims are decided by trial verdict, ${ }^{27}$ the parties' recognition of claimants' inability to coerce an immediate and fair recovery through the courts is the critical factor in settlement negotiations. ${ }^{28}$

Unlike most criminal and some civil trials, personal injury actions have not been expedited by improved pretrial procedures and more efficient calendar arrangements. ${ }^{29}$ In state courts, where the majority of personal injury claims are tried, the average time from service of process

22 Id. at 47 . This figure represents nearly one-third of the total economic loss sustained. Id. at 45 .

$23 \mathrm{Id}$. For example, where economic losses were in the $\$ 1,000-\$ 1,499$ range, tort recovery represented 56.6 percent of the reparations received, by amount of economic loss. Medical insurance represented 10.9 percent; life insurance, 6.1 percent; automobile medical insurance, 10.3 percent; collision insurance, 5.6 percent; and wage replacement (e.g., sick leave and workmen's compensation), 5.9 percent.

24 See, e.g., A. Conard et al., supra note 1, at 63, 195, 197.

25 ECONomic ConsEquencis, supra note 2, at 52.

$26 I d$. Delays in settlement have commonly been found to vary directly with the size of loss. See, e.g., Personal Injury Craims, supta note 2, at 87. See also A. Conard et al., supra note 1 , at 222-23. In the Michigan study, for instance, of "settlements under $\$ 1000$, 58 percent were made within six months, and 86 percent within one year. But among settlements of $\$ 1000$ to $\$ 2999$, only 28 percent were made within six months, and only 58 percent within a year." Id. at 222.

27 It has been estimated, for example, "that 193,000 claimants seek compensation for bodily injuries each year in New York City; that 39,000 of these settle or abandon their claims without consulting counsel; that another 77,000 settle or abandon their claims after consulting counsel but without instituting suit; that the remaining 77,000 sue, and of these, 7,000 reach trial, 2,500 going all the way to verdict." Rosenberg \& Sovern, supra note 1, at 1160. See also A. CoNARD et al., supra note 1, at 154-56.

28 See H. Zeisel, H. KALVeN, \& B. Buchrolz, supra note 1, at 111-12; Marshall \& Berg, supra note 4, at 33; Rosenberg \& Sovern, supra note 1 , at 1125 .

29 See, e.g., H. ZiIseL, H. KALven, \& B. BuchHolz, supra note 1 , at xxiv-xxv. 
to trial in 88 large, metropolitan jurisdictions is 21.7 months, ${ }^{30}$ and in counties with a population of more than 750,000 , it is 29.2 months. ${ }^{31}$

Although crowded dockets account for a sizeable part of this delay, the dilatory practices of lawyers are a significant additional factor. ${ }^{32}$ Counsel frequently cooperate in obtaining continuances, and courts readily grant desired postponements on pleas of conflicting trial dates. ${ }^{33}$ Even if counsel-induced delay were eliminated, the problem would still not be resolved since the estimated average waiting period in state courts from the time that parties file a statement of readiness ${ }^{34}$ for trial until the actual trial is 14.6 months. ${ }^{35}$

30 Institute of Judicial Administration, Gatendar Status Study-1971-State Trial Courts of Generat Jurisdiction-Personal. InJuRy CASES vi (1971). This figure represents a slight increase over the average figure of 20.7 months reported for 98 jurisdictions in 1970. Id.

31 Id. In the most populous counties the average elapsed time is often four years or more:

\begin{tabular}{|c|c|c|}
\hline Court and County & Population & $\begin{array}{l}\text { From Service of } \\
\text { Answer to Trial } \\
\text { (Average in Months) }\end{array}$ \\
\hline $\begin{array}{l}\text { Circuit Court, Cook } \\
\text { County (Chicago) } \mathrm{nl} .\end{array}$ & $5,427,237$ & 61.7 \\
\hline $\begin{array}{l}\text { Supreme Court, Bronx } \\
\text { County (Bronx) N.Y. }\end{array}$ & $1,441,403$ & 61.5 \\
\hline $\begin{array}{l}\text { Supreme Court, Rockland } \\
\text { County (Rockland) N.Y. }\end{array}$ & $2,8,897$ & 56.3 \\
\hline $\begin{array}{l}\text { Supreme Court, Kings } \\
\text { County (Brooklyn) N.Y. }\end{array}$ & $2,562,245$ & 51.9 \\
\hline $\begin{array}{l}\text { Supreme Court, New York } \\
\text { County (Manhattan) N.Y. }\end{array}$ & $1,509,327$ & 49.9 \\
\hline $\begin{array}{l}\text { Supreme Court, Westchester } \\
\text { County (White PIains) N.Y. }\end{array}$ & 888,314 & 49.6 \\
\hline $\begin{array}{l}\text { Court of Common Pleas, } \\
\text { Philadelphia County } \\
\text { (Philadelphia) Pa. }\end{array}$ & $1,927,863$ & 46.8 \\
\hline $\begin{array}{l}\text { Supreme Court, Nassau } \\
\text { County (Mineola) N.Y. }\end{array}$ & $1,413,012$ & 43.8 \\
\hline
\end{tabular}

Id. at viii. These figures represent a slight increase over those reported in 1970. INSTITUTE of Judicial administration, Galendar Status Studx-1970-State Trual Courts of GenERAC JURISDICTION-PERSONAL INJURY CASES vi, vii (1970).

32 See, e.g., Rosenberg, supra note 1 , at 35-37.

33 "When one lawyer asks for a continuance, his adversary usually goes along in deference to what the late Chief Justice Vanderbilt of New Jersey called 'the prevailing custom of professional courtesy of lawyers toward each other.' Even if the court is prepared to refuse to play the game of suiting its trial schedule to the convenience or tactics of counsel, it may have trouble forcing the issue .... Simultaneous demands for trial assignments frequently arise and courts tend to accept the plea of a conflicting trial engagement as a good ground for continuance." $I d$. at 36 .

34 In order to eliminate from dockets the many suits that are filed but never advanced to the trial stage, many state courts require a statement of readiness, affirming that a suit is in fact ready for trial. See INSTITUTE of Judiciat AdMINLSTRaTION-1971-STATE Trial Courts of General Jurisdiction-Personal Injury Cases vi-vii; H. ZeiseL, H. Kalven, \&. B. Buchrolz, supra note 1 , at 155-67.

35 Id. 
Delayed offers of reasonable settlements force almost every claimant to choose among three alternatives-he can accept the defendant's first offer, which except for the smallest claims is typically just a fraction of the economic loss sustained; ${ }^{36}$ he can refuse and await another offer; or he can retain a lawyer to negotiate or to file suit. Although each of the latter actions has been found to increase the amount of the eventual settlement, ${ }^{37}$ the desired bargaining effect on the defendant is not immediate: substantial delays can still be expected. ${ }^{38}$ For those claimants unable to sustain their losses during this waiting period, an equitable recovery becomes an impossibility.

The claimants most likely to be driven to accept an inequitable amount are those of low and moderate income status who have suffered economic losses of several thousand dollars. Not only are such claimants invariably less able to sustain losses for an extended period, ${ }^{39}$ but they also must rely on aids, such as their savings or borrowings from friends

36 A. CONARD et al., supra note 1, at 202-08. As might be expected, the first offer decreases, as a percentage of economic loss, as the claimant's economic loss increases. Id. at 204.

37 Studies have consistently shown that claimants represented by counsel recover a larger percentage of their economic loss than those unrepresented. See, e.g., Economic Consequences, supra note 2, at 51; Personal InJURy CLAIMS, supra note 1, at 47, 72-73; Franklin, Chanin \& Mark, supra note 5, at 16-17; Morris \& Paul, supra note 1, at 924. While it is, of course, possible that those claimants who seek counsel are the ones with better claims, the greater likelihood is that claimants are unable to assess for themselves the strength of their claims. Those who seek counsel are probably representative of all claimants, and they simply receive the advantage of a lawyer's ability to assemble the facts and articulate the legal grounds for a recovery. Morris \& Paul, supra note 1, at 924. See also Personal InJury Clatms, supra note 2, at 47.

It is less certain that filing a suit will increase the amount of recovery. A CoNARD et al., supra note 1, at 189; Franklin, Chanin \& Mark, supra 5, at 19. There is, however, some indication that the filing of a suit may induce a larger settlement. Economic CoNSEQUENCEs, supra note 2, at 51; Franklin, Chanin \& Mark, supra note 5, at 17-18.

38 The average delay until recovery increases when lawyers are retained; it is even greater when suits are filed.

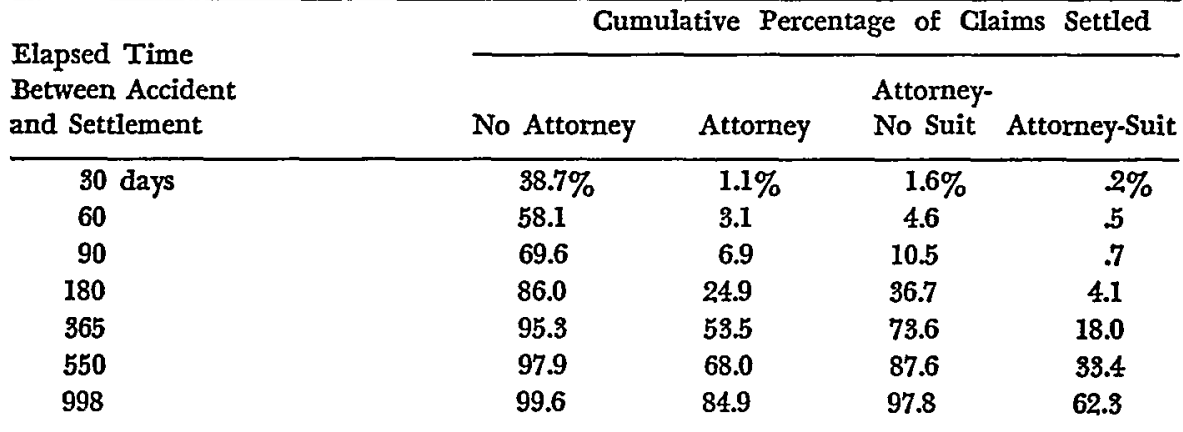

Personal Injury Ciaims, supra note 2, at 91.

30 A. Conard et al., supra note 1, at 221; James \& Law, supra note 4, at 78. 
or relatives, that have marginal utility when losses are in the range of several thousand dollars. ${ }^{40}$ Not surprisingly, studies indicate that, for large losses, the smallest percentages of economic loss are recovered by low income families. ${ }^{11}$ The great irony of recovery delay is that those claimants for whom noncompensatory recoveries may cause the most financial disruption and hardship are precisely those who can least afford to await equitable offers.

\section{Presettlement Aids Presentry Avamlable}

\section{A. Traditional Aids}

The difficulties faced by financially pressed claimants in covering their losses have, historically, received less attention than the problems of affording counsel or meeting court costs. During the latter half of the nineteenth century, contingent fee arrangements were approved by courts as a means through which low and middle income claimants could retain counsel, ${ }^{42}$ and in forma pauperis statutes were enacted to ensure that inability to meet court fees would not deny litigants access to the courts. ${ }^{43}$ In contrast, only informal and often inadequate provisions were developed to guarantee claimants compensation for their losses pending settlement or trial.

Presettlement aids that are presently available include benefit programs and attorney advances, neither of which provides extensive coverage or sufficient assistance. Although not designed to subsidize personal injury victims awaiting tort recoveries, funds from insurance and employee benefit programs are often received quickly enough to serve that function..$^{44}$ They do not, however, meet the total needs of all claimants. A 1970 study, for example, showed that less than 50 percent of persons seriously injured in automobile accidents received benefits from some type of hospital and medical insurance, and these benefits amounted to only 35 percent of economic loss. ${ }^{45}$ The corresponding figures for sick leave were 18 percent and 9 percent; ${ }^{46}$ for first party automobile insurance, 35 percent and 19 percent. $^{47}$

40 Morris \& Paul, supra note 1 , at 918.

41 Economic ConSEQUences, supra note 2, at 54; Morris \& Paul, supra note 1, at 914.

42 For the history of the contingent fee in this country, see F. MAcKrnNoN, supra note 12 , at 3-35.

43 See Willging, Financial Barriers and the Access of Indigents to the Courts, 57 Gro. L.J. 253, 255-58 (1967).

44 The comparative speed with which these funds are received can be attributed to the fact that fault need not be first proven; generally, mere demonstration of loss is sufficient to have the payment of compensation started. Economic CoNsEQuENCEs, supra note 2, at 36 .

45 Economic Consequences, supra note 2 , at 43,46 .

46 Id.

47 Id. 
Although nearly all injured parties receive benefits from at least one such program, ${ }^{48}$ and overlapping coverage provides additional immediate aid, other cash sources are frequently still necessary. Fully 20 percent of the victims included in the 1970 automobile injury sample used savings or sold property, 14 percent borrowed from friends or relatives, 5 percent were forced to have another household member go to work, 12 percent missed payments on other obligations, and 16 percent changed their living style. ${ }^{49}$ Even if these informal means could provide claimants with the funds needed to withstand delays, the necessity that they be used indicates an essential failing in the present tort recovery system. Moreover, where losses incurred are severe, these alternatives quickly prove inadequate. ${ }^{50}$

An additional source of temporary aid is the claimant's attorney. Pending a settlement or court award, a number of attorneys have loaned their clients money to help meet living expenses. ${ }^{51}$ Although this practice was widespread in some areas of the country ${ }^{52}$ and effectively enabled poorer claimants to await equitable recoveries, ${ }^{53}$ in 1955 the Legal Ethics Committee of the American Bar Association interpreted the Association's Canons of Professional Ethics to mean that all such loans were improper, ${ }^{54}$ reasoning that the practice not only allowed an attorney to "purchase an interest... in the litigation which he is conducting," in violation of Canon 10,55 but also forced him to "represent conflicting interests," in violation of Canon $6 .{ }^{56}$ Since the Committee's view was not binding, ${ }^{57}$ courts generally continued to uphold the practice. ${ }^{58}$ In 1970, however, the Canons were superseded by the Code of Professional Responsibility, ${ }^{59}$ which accepted the committee's view and

48 Id. at 37; A. CoNARD et al., supra note 1 , at 148.

49 ECONOMic CONSEQUENCES, supra note 2 , at 57.

50 See, e.g., Morris \& Paul, supra note 1, at 922.

51 Comment, supra note 12.

52 Id. at 1419 n.1.

53 Id. at 1419.

54 ABA Comm. on Professional Ethics, Opinions, No. 288 (1954), in 41 A.B.A.J. 33 (1955).

55 aba Canons of Professional Ethics No. 10.

50 Id. No. 6. The committce also found that if the practice was publicized, Canon 27 would be violated. "It is unprofessional to solicit professional employment by circulars, advertisements, through touters or by personal communications or interviews not warranted by personal relations." Id. No. 27.

57 The Opinions of the Legal Ethics Committee, given in response to inquiries, are purely advisory. H. DRINKER, L.EGAL ETHICS 30-32 (1953).

58 See, e.g., In re Ruffalo, 249 F. Supp. 432, 440-43, 445 (N.D. Ohio 1965), aff'd, 370 F.2d 447 (6th Cir. 1966), aff'd, 390 U.S. 544 (1968). See also Comment, supra note 12, at 1424-25.

59 The Code had been drafted as a replacement for the Canons. It was adopted by the House of Delegates of the American Bar Association on August 12, 1969, to become effective for Association members on January 1, 1970. ABA Code of Professional Responsibility i, ii. 
specifically prohibited attorneys from advancing funds to their clients for living expenses. ${ }^{60}$ At present, the Code has been officially adopted by the highest courts of forty-two states; in five other states official adoption has been recommended by the state bar associations. ${ }^{61}$ Since adoption means that violators are subject to disbarment, ${ }^{62}$ it can be assumed that few claimants are still aided by this source, although information is obviously difficult to obtain.

\section{B. Two Alternative Sources of Assistance: Advance Payments and No-fault Automobile Insurance}

The insufficiency of informal sources to satisfy the presettlement needs of many claimants has led to the recent development of two additional means of assistance. They too provide only limited coverage, however, and without basic changes it is unlikely that they will add substantially to the traditional sources.

1. Advance Payments. Large liability insurers now follow a general policy of providing selected claimants with advance payments ${ }^{63}$ to help them meet hospital and medical expenses and to cover wage losses until a settlement is negotiated. ${ }^{64}$ The payments are typically made only when the limits of the applicable insurance policy are adequate ${ }^{65}$ and the insurer believes the claim is one of "clear" or "probable" liability. ${ }^{68}$

60 Canon 5 of the code states generally that "a lawyer should exercise independent professional judgment on behalf of a client." $I d$. No. 5. A disciplinary rule accompanying this canon provides that "while representing a client in connection with contemplated or pending litigation, a lawyer shall not advance or guarantee financial assistance to his client." Id. DR 5-103 (B). Disciplinary rules are mandatory; they "state the minimum level of conduct below which no lawyer can fall without being subject to disciplinary conduct." Id. at 1.

61 The five states in which recommended adoption has not yet occurred are Connecticut, South Carolina, Massachusetts, Montana, and Wyoming. The only states in which no action has yet been taken, by the state bar association or supreme court, are California, North Carolina, and Alabama. List prepared by Professional Ethics Committee, American Bar Association, June 6, 1972 (copy on file at The University of Chicago Law Review).

62 Although the Code is technically binding only on ABA members, its adoption by a state supreme court binds all lawyers practicing in that state. See Brown, A.B.A. Code of Professional Responsibility: In Defense of Mediocrity, 5 VALPARIso L. REv. 95 (1970); Sutton, The American Bar Association Code of Professional Responsibility: An Introduction, 48 TEXAS L. REv. 255, 256 (1970).

63 See note 8 supra.

64 See, e.g., DeFEnSE Research INSTITUTE, supra note 8, at 1; J. O'Connelr, supra note 8, at 22-23; Ross, New Developments in the Settlement of Automobile Liability Claims, 48 J. URBAN L. 449, 452 (1971); Schroeder, Carpenter \& DesChamps, supra note 8, at 550.

65 Program: Legal Aspects of Partial Payments Made on Liability Claims in Advance of Final Settlement, in Proceedings of ABA Section of Insurance, Negligence aNd ComPENSATION LAW 499, 514 (1967).

66 J. O'Connel, supra note 8, at 25; Schroeder, Carpenter \& DesChamps, supra note 8, at 550 . 
A release from liability is not required as a condition for receiving the payments; ${ }^{67}$ generally, a recipient must agree only that the amount advanced is to be deducted from any settlement or judgment. ${ }^{68}$

The insurers' motives for initiating advance payment programs are pragmatic: it is believed that providing advance payments can save money by, in part, inducing recipients who might otherwise have had difficulties in securing presettlement aid to express their appreciation of an unexpected offer by not seeking counsel or at least by lowering settlement demands. ${ }^{60}$ Although some claimants who could not have withstood delay at all may receive larger settlement offers than would have been necessary had no advance payments been made, the policy is believed to result in an overall savings by promoting lower settlements in most cases. This belief has been confirmed by data on the use of advance payments in reports of comparative studies by insurers. ${ }^{70}$

The most serious drawback of advance payments from the perspective of the personal injury claimant is not, however, the tendency to accept lower settlements. It is, rather, the programs' limited applicability-claimants remain unaided if they are injured by one who is uninsured or insured by a company that does not provide advance payment. Even those claimants dealing with insurers who provide advance payments may not be assisted since the reluctance of many adjustors to depart from traditional settlement techniques, which involve less time and paperwork, has resulted in advance payments being dispensed more conservatively than management would like. ${ }^{71}$ The relative unavailability of advance payments is reflected in the finding that in the automobile accident area, where advance payments are most widely used, only 5.2 percent of paid claimants received advance payments, ${ }^{72}$ and that the amount received was just 2.5 percent of the total payments

$67 \mathrm{~J}$. O'CONNELI, supra note 8, at 23; Ross, supra note 65 , at 452 .

68 Id. Even if there has been no agreement, insurers have strong authority for deducting the advanced amount. See, e.g., Edwards v. Passarelli Bros. Automotive Serv., Inc., 8 Ohio St. 2d 6, 221 N.E.2d. 708 (1966). In addition, some states have statutes allowing deductions when advance payments have been made. See, e.g., KAN. Stat. ANN. ch. $40 \$ 275$ (Supp. 1971); NEB. REV. Stat. \& 25-1222.01 (Supp. 1969); N.C. GEN. Stat. Sec. 1 \& 540.3 (Supp. 1971).

$69 \mathrm{~J}$. O'Connetr, supra note 8, at 23; Procezdings of ABA, supra note 66, at 515; Schroeder, Carpenter \& DesChamps, supra note 8, at 553.

70 Ross, supra note 65, at 453 .

71 Id.

72 PERSONAr INJURY CLAIMS, supra note 2, at 94. Of those claimants who were represented by an attorney, only 2.3 percent received advance payments; of those unrepresented, 7.7 percent were recipients. $I d$. at 96 . These figures may underrepresent the impact of advance payments since their use is believed to have increased since the data was compiled. Id. at 94. 
made by the insurer. ${ }^{73}$ Unless the present pattern changes, it is unlikely that advance payments will significantly improve the dilemma of financially pressed claimants.

2. No-fault Automobile Insurance. No-fault automobile insurance, which was first given structure in 1965 in the Keeton-O'Connell Basic Protection Plan, ${ }^{74}$ is an attempt to lessen the problems of delayed recovery by eliminating elements and procedures of the tort system. Under the Basic Protection Plan, automobile owners must purchase insurance policies that will compensate them, or their families and passengers, for at least $\$ 10,000$ of economic loss regardless of fault. ${ }^{75}$ The right to recover in tort is preserved only for those cases involving more than $\$ 10,000$ of economic loss or more than $\$ 5,000$ of conscious pain and suffering. ${ }^{76}$ Since such cases are few in number, most injured parties can expect to recover on a no-fault basis from their own insurer and thus avoid the delays of attempting to recover in tort.

While the Basic Protection Plan presents certain elements of unfairness to some claimants, ${ }^{77}$ on the whole it offers a substantial solution to the problem of delayed recovery. The plan has spawned a variety of different types of no-fault schemes, ${ }^{78}$ many of which go even further

73 Id. at 96.

74 See $\mathbf{R}$. Keeton \& J. O'Connelx, supra note 4. See also R. KeEton \& J. O'Connerr, after Cars Crash-The Need for leegal and Insurance Reform (1967); J. O'Conneir, supra note 8; Keeton, Basic Protection Plan-An Automobile Insurance Reform Tailored to the Need, 16 LA. B.J. 287 (1969); Keeton, Compensating the Injured Claimant: The Keeton-O'Connell Plan, 44 F.R.D. 122 (1968); Keeton \& O'Connell, Basic Protection: A Rebuttal to Its Critics, 53 A.B.A.J. 633 (1967); Keeton \& O'Connell, Basic Protection for Traffic Accident Losses, 43 Notre DAME LAw. 184 (1967); Keeton \& O'Connell, Basic Protection Automobile Insurance, 1967 U. IIL. L.F. 400 (1967); O'Connell, Balanced Approach to Auto Insurance Reform: O'Connell Answers His Critics, 41 U. CoLo. L. REv. 81 (1969); O'Connell, Basic Protection-Relief for the Ills of Automobile Insurance Cases, 27 LA. L. REv. 647 (1967). For some of the commentary on the Basic Protection Plan, see Hold, Basic Protection for the Traffic Victim-The Keeton and O'Connell Proposal "too far or not far enough," 35 INs. Counser. J. 120 (1968); Jones, A Criticism of the Keeton-O'Connell Plan, 29 ArA. LAW. 293 (1968); Julien, Keetor-O'Connell: Myth or Panacea, 40 N.Y.S.B.J. 256 (1968); Kluwen, Analysis of the Criticisms of the Fault System, 1967 INs. L.J. 389; Knepper, The Automobile Compensation Controversy, 26 WASH \& LEE L. REv. 17 (1969); Markhof, Compensation Without Fault and Keeton-O'Connell Plan: A Critique, 43 Sr. JoHn's L. REv. 175 (1968); Marryott, Testing the Criticisms of the Fault Concept, 35 INS. Counser J. 112 (1968); Sargent \& Corboy, The Basic Protection Plan-Panacea or Inequity, 44 Notre Dame LAw. 51 (1968); Note, Keeton-O'Connell Plan: A Catalyst in the Search for a Workable Solution to the Automobile Accident Compensation Problem, 17 BuFraco L. REv. 849 (1968).

75 R. KEETON \& J. O'CoNNELI, supra note 4, at 274-76.

$78 \mathrm{Id}$. Under the plan, policyholders are granted the option of buying first party pain and suffering protection to cover the amount not recoverable in tort.

$\mathbf{7 7}$ For a discussion of some of the inequities that have been pointed out, see authorities cited note 74 supra.

78 See, e.g., Keeton, Routes to Reform of the Automobile Reparations System, 74 W. VA. L. REv. 2 (1971). 
toward removing automobile accident claims from the tort system. At present, though, only a few state legislatures have responded to the plan by enacting some type of no-fault statute. ${ }^{79}$ All of these plans, however, retain many more vestiges of the tort system than does the Basic Protection Plan. For example, in Massachusetts, which was the first state to adopt a no-fault insurance law, ${ }^{80}$ a policyholder is required to have first party protection, covering medical payments and 75 percent of wage loss, of only $\$ 2,000 .^{81}$ In the not infrequent cases where losses exceed $\$ 2,000$, not only must an injured party bring an action in tort in order to obtain full recovery, but he might also be denied his first party benefits until the fault claim is settled. ${ }^{82}$

Even if the first party coverage in these plans is extended, no-fault insurance would still be inadequate to meet all needs for claimant aid. While there is no reason why no-fault insurance could not be used in other areas, ${ }^{83}$ for the foreseeable future its benefits are limited to those claimants injured in automobile accidents. Furthermore, the number of potential claimants likely to benefit from no-fault coverage is rela-

79 See, e.g., Connecticut Public Act No. 273 (1972); Florida Automobile Reparations Reform Act, ch. 71-252 (1971); InL. Rev. STAT., ch. 73, \$\$ 1065.150-1065.163 (1971); MAss. GEN. LAwS ANN. ch. 90, §§ 34A, 34D, 34K, ch. 175, \& 113B; ch. 231, § 6 (1970); ORE. REV. STAT., ch. 523 (1971).

The Illinois Supreme Court has enjoined that state's no-fault law from going into effect. Grace v. Howlett, 51 IIl. 2d 478, 283 N.E.2d 474 (1972). The court held that the statute was violative of several specific state constitution provisions, and avoided a determination of whether no-fault inherently violated equal protection and due process guarantees. In Massachusetts, however, the no-fault statute has been upheld as nonviolative of federal and state rights to equal protection and due process. Pinnick v. Cleary, - Mass. -, 271 N.E.2d 592 (1971).

80 Massachusetts Senate Bill 850 was signed into law on August 13, 1970 and became effective on January 1, 1971. Puerto Rico has had a very limited no-fault law since January 1, 1970. Ghiardi \& Kircher, Automobile Insurance: An Analysis of the Massachtrsetts Plan, 21 SYRACuSE L. REv. 1135 (1970). For commentary on the Massachusetts plan, see Keeton \& O'Connell, Alternative Paths Toward Nonfault Automobile Insurance, 71 CoLum. L. REv. 241, 251-54 (1971); Kenney \& McCarthy, "No-Fault" in Massachusetts, Chapter 670, Acts of 1970-A Synopsis and Analysis, 55 Mass. L.Q. 23 (1970); Ryan, Massachusetts Tries NoFault, 57 A.B.A.J. 431 (1971); Comment, The Massachusetts "No-Fault" Automobile Insurance Law: An Analysis and Proposed Revision, 8 HARv. J. LEGrs. 455 (1971).

81 MAsS. GEN. LAWS ANN. ch. 90, § 34A (1970).

82 Nonfault payments are not due until disposition of a fault claim. MAss. Gen. LAws ANN. ch. 90, § 34M (1970). As Professors Keeton and O'Connell read the statute, this provision may be taken to mean that someone pursuing a tort claim may not immediately receive his first party benefits. They suggest, however, that the provision might easily be circumvented. Keeton \& O'Connell, supra note 80, at 253 n.54.

83 One of the authors of the Basic Protection Plan, Professor O'Connell, has suggested that the no-fault concept should be adopted to cover injuries suffered from household products. N.X. Times, May 21, 1972, at 30, col. 1. Professor O'Connell had noted earlier, however, that while no-fault was desirable in other areas, only in the automobile accident context was there a legal and insurance system readily transposable into no-fault. O'Connell, The Future Mix of No-Fault Insurance, Other Private and Public Health and Wage Loss Coverages, and the Casualty Insurance Industry, 1972 Iss. L.J. 30. 
tively small. The opposition to no-fault insurance by trial lawyer groups and part of the insurance industry has not only diluted those plans that have been adopted, but has also thwarted the effort to have no-fault enacted in many other states. ${ }^{84}$ This opposition has been responsible, in part, for the rejection of no-fault in nearly two dozen states. ${ }^{85} \mathrm{~A}$ number of other states have indefinitely postponed action on no-fault bills. ${ }^{86}$ In short, action by state legislatures to make no-fault widely available seems unlikely, and, since the federal no-fault bills seem far from passage, the possibility that the states will be forced to adopt meaningful no-fault programs in order to meet federal standards appears similarly remote. ${ }^{87}$ As a practical matter, then, the expansion of no-fault beyond its present limited borders cannot be expected in the near future.

Thus, the problem of assisting needy claimants in avoiding unfair settlement offers remains. The aids presently available have proved inadequate, and, although advance payments and no-fault automobile insurance have recently been introduced to supplement the traditional aids, their present and foreseeable impact seems insignificant in light of the magnitude of the problem.

\section{The English Interim Payment Plan}

\section{A. Description of the Plan}

In recognition of the inequitable results of settlement and court de-

84 See, e.g., Keeton \& O'Connell, supra note 80, at 244; N.Y. Times, May 16, 1972, at 1, col. 3.

85 No-Fault: A Legislative Bomb of 1972, 8 Triar, Jan.-Feb., 1972, at 8.

86 Id.

87 The main no-fault bill in the Ninety-second Congress is S. 945, introduced by Senators Hart and Magnuson on February 24, 1971. S. 945, 92nd Cong., 1st Sess. (1971). The bill is similar to the one that Senator Hart introduced in the previous Congress but that received no Senate action. See S. 4339, 91st Cong., 2d Sess. (1970). Under the provisions of S. 945, the states would be given until July 1, 1974, to pass a no-fault bill meeting the standards set forth in the Senate bill. (For those states whose legislatures do not meet again until 1974, the deadline would be extended until July 1, 1975.) Among the standards is the requirement of first party insurance that would provide at least $\$ 25,000$ for medical expenses and at least $\$ 75,000$ for rehabilitation and other economic losses. The insurance would be compulsory for all motorists. Suits for the recovery of pain and suffering would be barred except in cases involving permanent, serious disfigurement, permanent, signifcantly incapacitating loss of body function, or six months of disability. Property damage would not be covered by the bill, but insurers would be required to offer optional first party insurance for property damage. All of those states that presently have no-fault laws would be required to revise them to meet the federal standards. No current state law even approaches the minimum standards in the Hart-Magnuson bill. See N.Y. Times, May 25, 1972 , at 78 , col. 1 .

S. 945 was approved by the Senate Commerce Committee on May 24, 1972, by a 13-4 vote. On August 8, 1972, however, the Senate voted 49-46, to send the bill to the Judiciary Committee for further study, thus ending any chance for Federal no-fault legislation by the Ninety-second Congress. N.Y. Times, Aug. 9, 1972, at 1, col. 5. 
lay, ${ }^{88}$ the English Parliament authorized, in the Administration of Justice Act of 1969, judicial adoption of interim payment. ${ }^{89}$ As effected in 1970 by the Rules of the Supreme Court of Judicature, ${ }^{90}$ the interim payment plan permits a plaintiff in a personal injury action to obtain a pretrial award of damages from the defendant.9I

The purpose of this interim judicial relief plan is "to mitigate the hardship or prejudice in the case of innocent victims of accidents which may be occasioned during the interval between the commencement of an action for personal injuries and its ultimate trial." 92 Unlike remedies

88 The problems caused by delays in personal injury recovery were, in the late 1960's, also recognized to exist in England. One commentator observed that a reason "why successful claimants often recover less than full indemnity is that most injury claims are settled out of court between parties whose bargaining position is very unequal. The uncertainties of litigation and the preparations for trial are often less of a strain on a large corporate enterprise or insurance company than they are on an injured claimant. Hence the delays of litigation tend to favour the defendant. It is rather unsavoury that the bargaining position of the claimant, although directly proportionate to the estimated value of his claim, is inversely proportionate to the urgency of his financial need." T. IsON, THE FORENSIC LOTTERY 14 (1967).

"It may truly be said that, in so far as our present procedures permit avoidable delays, the law is still not equally available as a protection for the rich and the poor. Too many plaintiffs simply cannot wait for the day when their case will be tried and therefore settle for an inadequate sum." Committee on Personal Injuries Litigation, First Report, CMND. No. 3691, at 31 (1968) [hereinafter cited as WINN CoMmrTree REPORT].

80 The Administration of Justice Act 1969, c. 58, iv, § 20. Parliament's action was in response to the recommendations of the Winn Committee, which had been appointed in 1966 by the Lord Chancellor to study the problems of personal injury litigation. Wrin COMMTTEE REPORT, supra note 88, at 13. The Winn Committee's interim payment plan was adopted by Parliament with only a few modifications. 25 HALSBURY's Statutes of ENGLAND, The Administration of Justice Act 1969, § 20, Notes (3rd. ed. 1970); Borrie \& Pyke, Administration of Justice Act 1969, 119 NEw L.J. 1012, 1013 (1969).

90 StAt. INSTR. 1970, No. 944, at 2932. The Rules of the Supreme Court of Judicature govern the procedure of the Queen's Bench Division, which is the division of the High Court of Justice that deals with, inter alia, personal injury matters. Formulated by the Rule Committee of the Supreme Court, the rules have statutory authority. The Supreme Court of Judicature Act of $1925,15 \& 16 \mathrm{Geo} .5$, c. 49, \& 99. For basic descriptions of the English judicial system and the Rules of the Supreme Court, see R. M. JACkson, THE Machinery of Justice in England 22, 30-42, 58-59 (1960); Odgers' Principles of Pleading and Practice in Crvic Actions in Figh Court of Justice 1-5 (20th ed. G. Harwood 1971) [hereinafter cited as Odgers']; $R$. WALkER \& M. WALKER, ThE ENGLISH Legal SysteM 15358, 223 (1967). The interim payment rules adopted by the Rule Committee were virtually identical to those that the Winn Committee had recommended. See WINN CommrrteE REPORT, supra note 88, at 197.

91 For a brief description of interim payment, see ODGERs' supra note 89, at 54-55.

92 Supreme Court Practice (Supp. 1970), supra note 16, at If 29/7-17/3. More specifically, the interim payment procedure "is designed to relieve the innocent or virtually innocent plaintiff of undue hardship while awaiting the final outcome of his action, to redress the balance during the interval before trial between the strength of the one party and the weakness of the other, to dispose the parties towards a fair and reasonable compromise or settlement of actions for personal injuries ...."Id. See also WINN CoMMIrTEE REPORT, supra note 89 , at 32 . 
such as attachment and garnishment, interim payment is not designed to assure a plaintiff that a favorable judgment, once obtained, can be enforced. ${ }^{93}$ Instead, it is designed to provide a plaintiff with the necessary funds to meet his losses until a favorable judgment can be obtained. Collaterally, interim payment strengthens the plaintiff's bargaining position and increases the opportunity for an equitable pretrial settlement. Defendants' interests are protected by ensuring that a claimant receives only that which he could obtain at trial.

Under the Rules, an injured plaintiff may apply by summons for an interim payment order at any time after service of process and expiration of defendant's opportunity to enter an appearance. ${ }^{94}$ The summons must, inter alia, state the grounds on which the application is made and be accompanied by affidavits and records verifying the amount of the damages claimed. ${ }^{95}$ Following service of the summons and accompanying papers, ${ }^{96}$ a hearing on the application is conducted by a master of the Queen's Bench Division.97

The master's power to enter an interim payment order and to determine the amount to be paid is discretionary. ${ }^{98}$ The Rules provide three threshold criteria for issuing an interim payment order; the plaintiff must prove at the hearing either that: (1) the defendant has admitted, expressly or impliedly, liability for the plaintiff's claim;99 (2) the defendant has already been adjudged liable for the damage, ${ }^{100}$ through default, summary judgment, or a split trial; ${ }^{101}$ (3) the plaintiff would succeed at trial on the issue of liability and would recover judgment for damages, without there being any substantial reduction for fault on the part of the plaintiff. ${ }^{102}$ The defendant bears the burden of raising

93 For a discussion of the differences between interim payment and garnishment and attachment, see note 149 infra.

94 Supreme Court Practice (Supp. 1970), supra note 16, at O. 29, r. 10; If 29/9-17/4; If $29 / 9-17 / 6$.

95 Id. at O. 29, r. 10.

96 Id. at O. 29, r. 11.

97 Id. at O. 29, r. 12. The phrase "the Court" is to be interpreted in this context to mean a Master of the Queen's Bench Division. See ODGERs', supra note 89, at 5. A Queen's Bench Division Master is authorized to hear and decide nearly all interlocutory applications. I. Jacob, P. Adams, J. Neave \& K. McGuffie, The Supreme Court Practice O. 4, r. 2 (1967) [hereinafter cited as Surreme Court Practice]. See also R. WALKer \& M. WALKER, supra note 89, at 22 .

98 Supreme Court Practice (Supp. 1970), supra note 16, at If 29/9-17/12.

99 Id. at o $29 / 9-17 / 9$.

$100 \mathrm{Id}$.

101 Id. The split trial, where issues of liability are determined before the question of damages, has recently been authorized by the Rule Committee. $I d$. at 0 . 33 , r. 4. This procedural innovation was also an outgrowth of the Winn Committees recommendations. See WINN COMMITTEE REPORT, supra note 88 , at 135-43.

102 Supreme Court Practice (Supp. 1970), supra note 16, at of 29/9-17/10. The English 
a defense such as contributory negligence and proving its substantiality. ${ }^{103}$ The rationale for an interim payment order under any of the three grounds is that:

[t] he plaintiff has already succeeded or is certain to succeed on the issue of liability in the action, and therefore while it may be an advantage to the plaintiff to be able to receive an interim payment on account of his damages, there can at the same time be no injustice to the defendant to have to pay such an interim payment before the trial, since he will ultimately have to pay a larger sum at the trial. ${ }^{104}$

In addition to determining that the application meets at least one of the necessary grounds, the master must also find the defendant financially capable of meeting an interim payment order. The statutory standards governing the master's judgment are broad. The defendant must be either "a person who is insured in respect of the plaintiff's claim,"105 "a public authority,"108 or "a person whose means and resources are such as to enable him to make the interim payment."107

The only legislative guidelines for assessing the amount to be paid are that the award be "just" and not exceed a "reasonable proportion" of the damages that the master thinks likely to be recovered at trial.108 Several considerations affect this determination: (1) the extent of hardship to the plaintiff and members of his family, (2) the urgency of his need to mitigate this hardship, (3) the intended use of the money, and (4) the estimated interval between the application and time of the final award or assessment of damages. ${ }^{109}$ The master also determines the

law for cases involving contributory negligence is that "the plaintiff's damages are to be reduced by the court to such degree as appears just and equitable having regard to the plaintiff's share of the responsibility for what has happened." P. ATTYAH, AccidENTS, CoMPENSATION AND THE LAW 147 (1970); see The Law Reform (Contributory Negligence) Act of 1945, 8 \& 9 Geo. 6, c. 28; P. ATTYAH, supra, at 148-54.

103 "What is substantial for this purpose depends upon the circumstances of each case and is not to be resolved by references to percentages, above which the reduction would be substantial and below which it would not." Supreme Court Practice (Supp. 1970), supra note 16 , at $929 / 9-17 / 10$.

104 Id., at I 29/9-17/9.

$105 I d$, at 0.29, r. 12 .

$106 I d$.

$107 I d$.

$108 I d$. While normally a plaintiff simply seeks an order for an interim payment "of such amount as the court thinks just," he may specify the amount sought. "If he does so, it may induce the defendant to consent, in which case, or where the parties otherwise agree, the court will make an order by consent." $I d$. at $\uparrow 29 / 9-17 / 12$. The Winn Committee had recommended a limit of one-third of the likely recovery at trial. WINN CoMmITTEE REPORT, supra note 88 , at 34 .

109 Supreme Court Practice (Supp. 1970), supra note 16, at q 29/9-17/12. 
manner and form of the interim payment; he generally orders the money paid directly to the plaintiff, rather than into court, ${ }^{110}$ and in a lump sum, rather than in installments. ${ }^{111}$

If the action reaches trial, facts relating to the interim payment order cannot be pleaded or communicated to the judge until resolution of all questions of liability and damage. ${ }^{12}$ At the trial's conclusion, the defendant may seek an order crediting to the judgment the amount of the interim payment. ${ }^{113}$ If the judgment is for the defendant or the interim payment exceeds the amount awarded to the plaintiff, the court can order restitution. ${ }^{114}$

As with any interlocutory decision of a master, disposition of an interim payment application may be appealed directly to a judge of the Queen's Bench Division. ${ }^{115}$ An appeal, however, does not normally stay a master's order. ${ }^{116}$ Absent appeal, a plaintiff denied an interim payment order or granted an arguably insufficient amount has the right to make subsequent applications, provided "a change in circumstances" can be shown. ${ }^{117}$

\section{B. Analysis of Interim Payment}

In the two years since its inception in England, interim payment has not been studied in any detail. A prominent master has observed, however, that the interim payment rules "have been and are being quite generally used .... This new procedural device has done much to alleviate hardship and restore some balance between the parties in the litigation."'118

The advantages of interim payment are clear when compared to American aids for financially pressed claimants. First, eligibility is not limited to personal injury claims arising from a particular type of occurrence, such as an automobile accident, or in a particular geographic area, such as a no-fault state. Second, claimants are able to initiate the procedure that may lead to financial assistance, instead of relying on the self-interest of defendants or their insurance to impel voluntary offers of advance payments or loans. Moreover, the coercion of a court

110 Id. at $\mathbb{2} 29 / 9-17 / 13$. Payment into court is generally reserved for situations in which the plaintiff is a "person under disability" (e.g., infants or patients). See SUPREME CouRr Pracrice, supra note 97, at O. 80, r. 12.

111 Supreme Court PRACTICE (Supp. 1970), supra note 16, at of 29/9-17/13.

112 Id. at O. 29, r. 14; see Supreme CouRT Practice, supra note 97, at 0. 22, r. 7.

113 Supreme Court Practice (Supp. 1970), supra note 16, at O. 29, r. 16.

$114 I d_{0}$

115 See Supreme Court Practice, supra note 97, at 0. 80, r. 1.

$116 \mathrm{Id}$.

117 Supreme Court Practice (Supp. 1970), supra note 16, at O. 29, x. 11.

118 Letter from Master I. Jacob, supra note 17. 
order ensures that aid will be forthcoming. Third, the procedure for awarding interim payment ensures fair and uniform application of standards. Both claimants and defendants are aware, in advance, of the controlling rules. The master's role as a judicial officer guarantees impartial evaluation of an injured party's request for immediate aid and, at the same time, supervision of the general procedure by the Supreme Court of Judicature promotes uniformity. Fourth, the litigants' confrontation at the hearing is certain to accelerate both equitable settlements and, for those unable to settle, trial dates. At the hearing, usually held before any discovery, both sides have an early opportunity to assess the relative strength of their positions. In addition, they have the benefit of a master's disinterested assessment, which may provide a good indication of the potential disposition of the case before a judge and thus help prevent lengthy negotiations caused by an unrealistic appraisal of position by either of the parties. ${ }^{119}$ Even if a settlement is not reached, swifter resolution of the matter may result since the rules permit a master to "give directions as to the further conduct" of any case in which interim payment is sought; in some cases, he may order an early trial. ${ }^{120}$

Interim payment is not, however, the ideal solution to providing needed presettlement funds to personal injury claimants; several obstacles must be overcome before there can be any assistance. As a practical matter, though, these obstacles do not significantly hamper the effectiveness of interim payment.

The first obstacle is that a suit must be filed before a claimant can apply for interim payment. Since less than 20 percent of personal injury claimants in England ever file suit, ${ }^{121}$ more than 80 percent of the claimants are automatically excluded from the direct benefits of interim payment. ${ }^{122}$ In fact, however, those who do not file but who are recog-

119 The Winn Committee provides another reason for expecting accelerated settlements: "If a defendant has to pay a sum of money pursuant to an Order for interim payment, he may sometimes be encouraged to pay out the whole claim ...." WiNN CommirteE REPORT, supra note 88, at 32 .

120 Supreme Court Practice (Supp. 1970), supra note 16, at O. 29, x. 13.

$121 \mathrm{~T}$. Ison, supra note 88 , at 155 . Professor Ison estimates that 82 percent of personal injury claims are settled or abandoned before a suit is filed, 16 percent are settled or abandoned after a suit is filed, and 2 percent are determined by judgment. Because of the limitations of the research technique used (a mail questionnaire) and the comparatively small size of the sample, Professor Ison suggests that these figures may not be reliable. Id. at 129. The Michigan study suggests, however, that these figures are very accurate. In that study, 16 percent of the claimants filed suit. A. CoNRAD et al., supra note 1, at 154-56. But other studies have suggested higher percentages. See e.g., Franklin, Chanin \& Mark, supra note 8 , at $10-11$.

122 Since the Ison study's data was gathered before the institution of interim payment, the percentage of claimants automatically excluded may be less since some claimants who 
nized by defendants as qualifying for interim payment, benefit indirectly through the increased bargaining power that interim payment provides. In other words, a defendant can be expected, because of a natural desire to avoid the cost and trouble of a hearing, to bargain in the same manner with a claimant who could be awarded interim payment as with one who is a recipient. For those who could qualify, the availability of interim payment destroys the defendant's incentive to delay an equitable offer.

A second obstacle limiting interim payment is the legal costs incurred preparatory to a hearing. Since English law does not permit the use of the contingent fee in personal injury cases, ${ }^{123}$ the legal costs of seeking an interim payment order may serve to bar some claimants from applying. Of course, the cost of proving that losses will be shifted at trial varies with the type of case, but it has been estimated that an application for interim payment adds at least $\$ 180$ to the cost of proving a claim. ${ }^{124}$ Compared with the benefits of a preliminary recovery, this cost appears too small to deter many claimants from applying for interim payment, or to prevent defendants from perceiving claimants as eligible. And those otherwise unable to assume this additional cost will still be able to apply since they are likely to be represented by Legal Aid attorneys. ${ }^{125}$

The provisions relating to defendant's liability and financial state ${ }^{120}$ present more serious obstacles to eligibility. Liability is not always clear, and defendants may occasionally lack the resources to comply with an interim payment order. As a result, interim payment does not assist a claimant who appears to have only an even chance of succeeding at trial or who is confronted with a judgment-proof defendant. These restrictions do not, however, appear unreasonable. First, even though interim payment is confined to situations in which liability is probable, it would be inequitable to pressure defendants to agree to settlements for amounts in excess of any likely court award. Second, if successful at

otherwise might not have sued may now be encouraged to do so. No study has yet been undertaken, however, to determine interim payment's effect on the filing of suits.

123 MACKINNON, supra note 12 , at 38.

124 WINN COMmITtee REPORT, supra note 88, at 30.

125 The English Legal Aid scheme provides extensive assistance for civil litigants of low and moderate income. See Legal Aid and Advice Act of 1949, 12 \& 13 Geo. 6, c. 51. Those assisted contribute to the Legal Aid Fund in accordance with their ability to pay. R. $M$. JACKSON, supra note 94, at 282-83. See also T. Ison, supra note 88, at 5-6, 180-84; $\mathbb{R}$. WALKER \&: M. WALKER, supra note 90, at 209-17. The interim payment for an assisted claimant is paid directly to the Legal Aid attorneys, who can hold it to ensure that a charge for their services will be met. However, in such a case, it is likely that the interim payment will be released from the charge and given immediately to the plaintiff. SUPREME CourT PRActice (Supp. 1970), supra note 16, at ๆ 29/9-17/13.

126 Id. at O. 29, r. 12. 
trial, defendants should not be confronted with the prospect of having to seek restitution from plaintiffs unable to make it. Third, a lowering of the threshold requirements for interim payment might lead to an inordinate increase in applications, forcing masters to spend a large portion of their time hearing frivolous or unmeritorious applications.

Elimination of the present restrictions would distort the purpose of presettlement assistance within the confines of the tort system. The theory for interim payment is not that any injured party is entitled to pursue recovery without being faced with financial worries. The justification for interim payment is, rather, that if a claimant is virtually certain to succeed at trial, then his claim should not be effectively vitiated by financial inability to meet his losses pending trial. ${ }^{127}$ Of course, a party's losses may be equally great regardless of his chances of recovery. But unless the premise of liability in tort is to be altered, interim recovery should be restricted to those who will most likely be able to prove fault at trial.

\section{Interim Payment Plan: The Possibility of Adoption}

Because of differences in English and American rules of civil procedure, ${ }^{128}$ an attempt to adopt the interim payment scheme in this country would confront several problems. These difficulties are not insurmountable, however, and could be resolved by effecting several changes in the English model.

\section{A. Masters}

The Queen's Bench Division Masters are standing officers of the court who rule on nearly all pretrial motions. ${ }^{129}$ Under the English interim payment system, these masters are entrusted with the main decision making powers. There are no American counterparts to the Queen's Bench Division Master. The traditional right of a litigant to choose to have his suit tried by a judge or a jury has led most American jurisdictions to reject extensive use of masters. ${ }^{130}$ The masters currently used by state and federal courts play only limited roles in the judicial process. In the federal courts, cases are referred to a master ${ }^{131}$ in only excep-

$127 \mathrm{Id}$. at of $29 / 9-17 / 3$.

128 For an interesting comparison, see Kaplan, An American Lawyer in the Queen's Courts: Impressions of English Civil Procedure, 69 MrcH. L. REv. 821 (1971).

129 See Surreme Court PrActice, supta note 97, at O. 32, r. 11. An action in the Queen's Bench Division is assigned to a master as soon as the first summons is issued. From then on, the master deals with most of the interlocutory applications. See R. WALRER \& M. WALKER, supra note 90, at 222.

130 See, e.g., Kaufman, Masters in the Federal Courts: Rule 53, 58 CoLUM. L. REv. 452, 464 (1958).

131 The master in federal courts is not a specialist in civil procedure. As used in the 
tional circumstances; ; $^{132}$ the master's function is usually restricted to reporting to the court on particular pretrial issues ${ }^{133}$ and his findings are not necessarily binding on the litigants. ${ }^{134}$

In some American courts, the function of the Queen's Bench Division Master has been assumed by certain judges, often designated motions division judges. ${ }^{135}$ Because the supposed efficiencies have not generally materialized, the use of motions judges has been very restricted, ${ }^{136}$ and pretrial matters are typically decided by the judge who will try the case. Should an interim payment plan be adopted, therefore, it would be necessary that trial judges approve the applications. One difficulty with such a procedure is that the interim payment rules in England prohibit prejudgment disclosure of an award to the judge who tries the case. ${ }^{137}$ It is doubtful, however, that this would actually result in prejudice to one of the litigants. First, American judges commonly try cases in which they have made preliminary determinations similar to interim payment; the same judge, for example, decides the appropriateness of both preliminary and permanent injunctions. Second, if a litigant felt prejudiced by this procedure, he could have the case tried by a jury, which would be unaware of any interim payment order.

There are also certain advantages to permitting a judge to decide the interim payment question. His decision concerning the probability of a finding of liability and the extent of damages awarded at trial may be an even more accurate assessment than that made by a master because the judge will be conducting the trial and in some instances trying the issues himself. As a result, the judge's determination of interim damages may promote equitable settlements and avoid the costs of a trial.

It is also unlikely that interim payment applications would create an undue burden on the judiciary. The English experience demonstrates that relatively few applications are filed since the impact of interim pay-

Federal Rules of Civil Procedure, the term master includes "a referee, an auditor, an examiner, a commissionex, and an assessor." FED. R. Crv. P. 53(a).

132 "A reference to a master shall be the exception and not the rule. In actions to be tried by a jury, a reference shall be made only when the issues are complicated; in actions to be tried without a jury, save in matters of account and difficult computation of damages, a reference shall be made only upon a showing that some exceptional condition requires it." Id. 53(b).

133 A master's power may be limited in an order of reference to reporting on particular issues or performing particular acts. $I d$. 53(c).

134 In nonjury actions, for example, "the court after hearing may adopt the report or may modify it or may reject it in whole or part or may receive further evidence or may recommit it with instructions." Id. 53(e)(2).

135 See, e.g., N.Y.G. Civ. Prac. \& 2900.8 (1971).

136 See, e.g., Hooper, Calendar and Docket Control in Single Judge Systems, 50 F.R.D. 353 (1970).

137 Supreme Court Practice (Supp. 1970), supra note 16, at O. 29, r. 14. 
ment is reflected in the many claims that are settled without resort to suit. ${ }^{138}$ By increasing the percentage of equitable settlements, interim payment would further lessen the personal injury workload of the courts.

\section{B. Constitutional Questions}

An interim payment plan would present at least two important constitutional questions: (1) whether property is being taken without due process in violation of the fourteenth amendment; ${ }^{130}$ and (2) whether there is a right to a jury trial on an interim payment application under the seventh amendment. ${ }^{140}$

1. Due Process. The interim payment scheme raises a due process problem because it would allow the court to order a defendant to part with his funds, either to the plaintiff directly or to the court, prior to judgment. Prejudgment remedies are, of course, common in this country ${ }^{141}$ and have usually been held to satisfy due process standards..$^{142}$ The notable exception is Sniadach v. Family Finance Corp. ${ }^{143}$ in which the Supreme Court held that the Wisconsin wage garnishment statute, which afforded the defendant neither notice nor prior hearing, violated "the fundamental principles of due process." 144 The Court did not, however, find that any manner of prejudgment interference with a defendant's assets necessarily constitutes a deprivation of property without due process of law. Instead, it stated, first, that an extraordinary situation that might necessitate such a summary procedure had not been shown, ${ }^{145}$ and, second, that absent such a showing, an asset as crucial to the support of a family as a wage earner's salary cannot be taken without notice and a hearing. ${ }^{146}$ At the very least, the Court's holding in Sniadach can be interpreted to mean that summary proceedings not involving "the necessities of life"147 are constitutionally permis-

138 Letter from Master I. Jacob, supra note 17.

139 U.S. CoNST. amend. XIV, § 1.

140 U.S. CoNsT. amend. VII.

141 See, e.g., Patterson, Forward: Wage Garnishment-An Extraordinary Remedy Run Amuck, 43 WASH. L. REv. 735 (1968); Comment, Wage Garnishment in Washington-An Empirical Study, 43 WASH. L. REv. 743 (1968).

142 There is no due process problem whenever there has been notice and a hearing. But even when there has not been, the existence of extraordinary situations is enough to meet due process standards. See, e.g., Ewing v. Mytinger \& Casselberry, Inc., 339 U.S. 594 (1950); Fahey v. Mallonee, 332 U.S. 245 (1947); Ownbey v. Morgan, 256 U.S. 94 (1921). 143395 U.S. 337 (1969).

144 Id. at 342. The Court's opinion was written by Mr. Justice Douglas; only Mr. Justice Black dissented.

145 Id. at 339.

$146 I d$. at $340-12$.

147 Note, Some Implications of Sniadach, 70 CoLum. L. REv. 942, 949 (1970). 
sible. If notice and a hearing are provided, there is no constitutional problem regardless of the type of asset.

It may be argued that the stringent standards of Sniadach should be applied to interim payment, ${ }^{148}$ since, although garnishment and interim payment serve different purposes, ${ }^{149}$ they are both summary proceedings that can temporarily deprive a defendant of his property. The Sniadach standards do not, however, appear to present due process problems for the interim payment procedure. The English rules require that a defendant be notified of an interim payment application; ${ }^{150}$ improper notice invalidates an interim payment order. ${ }^{151} \mathrm{~A}$ hearing on the application is also a necessary part of the interim payment procedure. ${ }^{152}$ In addition, the funds used to meet an interim payment order cannot fairly be analogized to the working man's wages in Sniadach since no order is issued unless a defendant has sufficient "means and resources" to comply ${ }^{153}$ and, typically, the defendant subject to an interim payment order is an insurer.

The only potential for unfairness to a defendant ordered to make interim payment is that there is no guarantee of immediate restitution should the trial court eventually decide that the application decision was exrcneous. Restitution is, of course, no problem when there has been a garnishment or attachment because the assets are held by the court. But with interim payment, a defendant's assets are used by the plaintiff, who may not be able to make restitution by the time final judgment is rendered. Given the limited basis on which interim payment is ordered, the possibility of an error requiring subsequent restitution is not substantial. To eliminate, however, this small chance of unfairness, a plaintiff could perhaps be required upon receipt of interim payment to purchase a bond, secured by 10 percent of the payment, that

148 The standards set forth in Sniadach are presently the most stringent ones for prejudgment remedies. It is, of course, possible to argue that interim payment is potentially so much more injurious to a defendant than garnishment that stricter standards, such as the requirement of a full evidentiary hearing, should be imposed.

149 Garnishment, or attachment, is designed to ensure that a judgment upholding a plaintiffs claim can be executed. It is available only when there is reason to believe there will be difficulty in obtaining payment of judgment, as, for example, when the defendant has "absconded from the state or secreted himself therein, or is about to make a fraudulent conveyance or deplete his assets." Note, supra note 147, at 946-47. Interim payment, on the other hand is designed to assist the plaintiff immediately, not after judgment. It places the plaintiff into a more equitable bargaining position and enables him to meet his losses until trial.

150 Supreme Court Practice (Supp. 1970), supra note 16, at O. 29, r. 11.

$161 \mathrm{Id}$, at $\mathbb{2} 29 / 9-17 / 7$.

162 Id. at 0. 29, r. 12.

153 Id. 
would guarantee restitution. Such a requirement would be unlikely to impede substantially a plaintiff's ability to cover his losses.

2. Right to a Civil Jury. In England, a judge may order a jury trial in a personal injury action only in "exceptional circumstances;"154 under no circumstances does a litigant have a right to a jury trial in a personal injury action. ${ }^{155}$ Accordingly, the Supreme Court Rules provide for trial by judge in interim payment cases. In the United States, however, litigants in cases in which interim payment had been made would generally have a right to a jury trial. The seventh amendment would guarantee such a right in the federal courts. Although the seventh amendment has not been applied to the states through the due process clause of the fourteenth amendment, ${ }^{150}$ all but two states have similar guarantees in their constitutions. ${ }^{157}$

The less certain question is whether in hearings on interim payment applications courts would also have to offer litigants the choice of a jury. If interim payment is viewed as an equitable remedy, in the nature of garnishment, attachment, or injunction, there is, of course, no problem since the seventh amendment and the similar state provisions do not guarantee the right to a jury trial in equity actions. But because of the difficulty involved in determining precisely what is an equitable action, ${ }^{158}$ it seems safer to analyze interim payment as part of a common law action that constitutionally requires the right to a jury trial.

In a trilogy of seventh amendment cases-Beacon Theatres, Inc. $v$. Westover, ${ }^{160}$ Dairy Queen v. Wood, ${ }^{160}$ and Ross v. Bernard ${ }^{161}$-the

154 Supreme Court Practice, supra note 97, at O. 33, r. 5/2. See also Ward v. James, [1966] 1 Q.B. 273; Sims v. William Howard \& Sons, Ltd., [1964] 2 Q.B. 409. "It is a matter of discretion in most actions in the Queen's Bench Division, whether there shall be trial by jury. Matters to be taken into consideration include whether there is likely to be an acute conflict of evidence, and whether the issues either as to liability or damage are such as can better be decided by a consensus of ordinary lay opinion than a single judge." OdGERs', supra note 94, at 273. In practice, "an order for trial by jury is rarely made." Supreme Court Practice, supra note 97, at 0. 33, r. 5/2.

155 The right to a jury trial was severely limited by Parliament in 1933. See Administration of Justice Act of 1933, 23 \& 24 Geo. 5, c. 36, § 6. There is now a right to a jury trial only in cases involving fraud, libel, slander, malicious prosecution, false imprisonment, seduction, or breach of promise of marriage. $I d$.

156 See Melancon v. McKeithen, Civil No. 3390 (E.D. La., filed March 1, 1972).

157 The two exceptions are Colorado and Louisiana. Colo. Consr. art. 2, § 23; LA. Consr. art. 1, § 9, see James, Right to a Jury Trial in Civil Actions, 72 Yare L.J. 655 (1962).

158 See, e.g., Comment, From Beacon Theaters to Dairy Queen to Ross: the Seventh Amendment, the Federal Rules, and the Receding Law-Equity Distinction, $48 \mathrm{~J}$. URBAN $\mathrm{L}$. 459 (1971).

159359 U.S. 500 (1959).

160396 U.S. 469 (1962).

161396 U.S. 531 (1970). 
Supreme Court carefully prevented encroachments on the right to jury trial when a common law, or legal, issue was involved. ${ }^{162}$ In each case, the Court was concerned that a litigant's right to a jury trial on a legal issue might be lost because of the presence of equitable issues that had to be tried by a judge. In Beacon, the Court held that when a defendant's counterclaim presents legal issues, the fact that the plaintiff's claim is equitable cannot, except in the most imperative circumstances, deny the defendant a jury trial on his issues. ${ }^{163}$ Similarly, in Dairy Queen, the Court held that if the plaintiff has both equitable and legal claims-regardless of how incidental the legal claims are to the equitable ones-the defendant cannot be denied a jury trial on the legal issues. ${ }^{164}$ In Ross, the Court extended its earlier reasoning and ruled that in a stockholder derivative suit, which has historically been an equitable action, the plaintiffs cannot be denied a jury trial on the legal issues raised in the suit if the corporation, suing in its own behalf, would have been entitled to a jury trial on those issues. ${ }^{165}$

The Court's position in these cases can be attributed to the fact that litigants would have been barred from trying legal issues to a jury. This would not, however, be the case in interim payment hearings. Even if an application is viewed as part of the damage action, the defendant is not barred from a jury trial; he has the right to a jury trial on the action itself. Since a jury would not be informed of the interim payment application, and a bond would guarantee restitution, there would appear to be neither harm to the defendant nor any violation of the Supreme Court's decisions interpreting the seventh amendment in not having a jury decide the interim payment question.

\section{CONCLUSION}

Personal injury claimants unable to await an equitable tort recovery are frequently forced to make early settlements for inadequate amounts.

162 "Under the influence of Supreme Court decisions on the right to jury trial in civil cases in the federal courts, most observers seem to develop a Pavlovian reaction to a seventh amendment, jury trial issue whenever it arises. Any close question-and sometimes one that is not so close-is resolved in favor of the jury trial right without serious analysis of history, precedent, or policy." Shapiro \&: Coquillette, The Fetish of Jury Trial in Civil Cases: A Comment on Rachal v. Hill, 85 HARv. L. REv. 442 (1971). For further comment on the Supreme Court's recent activity in this area, see McCoid, Procedural Reform and the Right to Jury Trial: A Study of Beacon Theatres, Inc. v. Westover, 116 U. PA. L. REv, 1 (1967); Rothstein, Beacon Theatres and the Constitutional Right to Jury Trial, 51 A.B.A.J. 1145 (1965); Note, The Shareholders' Derivative Suit and the Constitutional Right to Trial by Jury, 7 TulsA L.J. 43 (1971); Comment, supra note 158; Note, Ross v. Bernard: The Uncertain Future of the Seventh Amendment, 81 YALE L.J. 112 (1971).

163359 U.S. 500, 508 (1959).

164369 U.S. 469,479 (1962).

165396 U.S. 531, 532-33 (1970). 
Aids traditionally available to help claimants meet their economic losses while they seek compensatory recoveries are of little assistance when losses are severe; and two new aids, advance payments and no-fault automobile insurance, are so limited in coverage and availability that they seem unlikely to improve the plight of claimants significantly. The English interim payment scheme offers a possible solution to the problem. Easily administered by the court system, it does not appear that its adoption in this country would be prevented by any insuperable practical or constitutional difficulties. 